\title{
The School Strategy in Multiple Intelligence Based Students' Character Building
}

\author{
Arifin Suking, Rismawaty Tajuddin
}

Universitas Negeri Gorontalo, Gorontalo, Indonesia

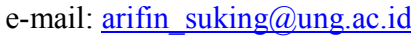

\begin{abstract}
This study examined multiple intelligence based students' character building strategy by focusing on school strategy in building intellectual, emotional and spiritual intelligence. This is a case study research with qualitative approach. Data were collected through interview, observation and documentation while the obtained data were analyzed by individual case analysis. Research finding showed that: 1) Strategies of the school in building students' intellectual intelligence were through (a) quiz competition, (b) students' creativity competition and (c) nou and uti competition. 2) School strategyies in building emotional intelligence were through (a) self defense training, (b) following both local and international competition and tournament, (c) perjusami program, and 3) school strategies in building students' spiritual intelligence are through (a) noon prayer in congregation, b) Islamic spiritual activity, c) dzikir and syukuran.
\end{abstract}

Keywords: Strategy, Character, Multiple Intelligence.

\section{INTRODUCTION}

School is a formally authorized organization to implement teaching and learning activity [1], [2], and [3] wrote that school is a service institution that conducts teaching and learning activities. As a place to learn, school has duty to implement qualified learning environment for students, school should implement its mission in attainment of various students' objectives, increase of ability, and comprehensive knowledge, including establishment of good character [4]. As a formal education institution, school is mandated to produce output with certain academic ability, skills, attitude and mental, and other personalities, thus, the outputs can pursue higher education level or work in certain jobs that suit their skills and ability. Therefore, certain process is needed in shaping those characters. Character education can be integrated in the teaching of every subject. Learning materials related to norms or values in each subject need to be developed, be made explicit, related with day to day context. Thus, the teaching of cognitive values is not only on cognitive level but also on internalization and practicing the values in the day to day life of the learners within the community.
The importance of character education in school is to help maximizing the child's cognitive ability. Character education has a very critical role in balancing between cognitive ability and psychological ability. Basically, human being has three potentials that can be developed in their existence, those are: intellectual quotient, emotional quotient, and spiritual quotient. These three quotients have to be synergized.

Education process in school is not only aimed at cognitive aspects, but also on the personality aspects, where both are necessary to be mastered by students. Hence, the students' will be able to have social intelligence, empathy toward others, good self-confidence, tolerance, patience, and creativity [5]. Within this education process, well directed and sustainable guidance are needed in form of multiple intelligence-based character education, which consists of (1) intellectual intelligence, (2) emotional intelligence, and (3) spiritual intelligence.

In order to create learners with good character and superiors, education process has to be periodically evaluated and improved. One of the improvements of education quality is through the emergence of ideas on the importance of character education in Indonesia education. This idea emerges because of the current education process that 
considered as not fully successful in developing Indonesian people with good character, as mandated within the law.

One of the institutions who needs to be considered in development of students' character is the vocational high school, because students in this level of education are experiencing changes toward adulthood where their psychological and physical aspects are changing. Also, because this group of students is different from public high school students, where the students in this type of schools are dominated by male students, hence, special attention and guidance are needed. Therefore, vocational schools are urged to have strategy in managing these challenges. These are the background for this research to focus on the school strategy in developing students' intellectual, emotional, and spiritual intelligences.

Character is related to unique or special attitude, or moral strength, or one's behavior pattern. Character is defined as specific way of thinking and behaving that are unique to each individual to live and work together, either in family, community, or the nation's life. Character is considered as values of human behaviors in relation to God, self, fellow human beings, environment, and their nations, which are manifested in their thoughts, attitude, feelings, statements, and actions based on religious norms, law, regulation, culture, customs, and esthetic [6]. Whereas character is defined as good unique values that are embedded within one self and manifested in behaviors [7]. Therefore, character is behaviors that are evident in daily lives, either in attitude or actions. Character is the moral values that differs one person to another. Character is defined as common live values, which are based on: peace, respect, cooperation, freedom, happiness, honesty, humility, love, responsibility, simplicity, tolerance, and unity. Therefore, character can also be defined as basic values that shape a person, which formed either through heredity or through environment, differs him/her from others, and manifested through attitude and behaviors in daily life.

Character education is defined as every positive thing done by the teachers and influences the character of the students. Wrote that character education is a conscious effort by a teacher to teach values to his/her students, while [6]. Character education is part of good learning and is a fundamental part of good education [8]. Therefore, it can be said that character education is a process of providing guideline for learners on how to become a decent human being who have character in their heart, mind, body, and feelings. Character education also can be described as values education, moral education, personality education that are aimed at developing the learners' ability to make good decisions, maintain good things, and create goodness in daily life whole heartedly.

Intelligence as a whole is individual ability to think and to act purposefully, and to manage and to master environment effectively [9]. Described intelligence in three components [10], namely: (1) ability to direct thoughts or actions, (2) ability to change actions directions when that action has been taken, and (3) ability to self-critic.

Intellectual intelligence is a general term that often used to describe mental attitude, which encompasses certain ability, such as: ability to think, plan, solve problems, think abstractly, understand ideas, use language, and learning. Intellectual intelligence is closely related to cognitive ability owned by individuals. Some characteristics of intellectual intelligence which emphasizes the ability to understand problems with the following characteristics : (1) contain certain degree of difficulty, (2) complex, (3) abstract, (4) economic, (5) directed toward certain purposes, and (6) based on its source of problems [11]. Formulates concept of intelligence, which popular as multiple intelligence in seven types of intelligence, namely: (1) linguistic, (2) mathematic-logic, (3) spatial, (4) music, (5) agility, (6) interpersonal, and (7) interpersonal [12]. The characteristics of high intelligence are: (1) the existence of ability to understand and solve mental problem quickly, (2) ability to remember, (3) high creativity, and (4) advance imagination.

Emotional intelligence is defined as ability to sense, understand and effectively implement ability and emotional sensitivity as source of energy, information, connection, and humane influence [13]. Emotional intelligence is ability to "listen" to emotional whisper, and to use that as important source of information to understand one self and others to achieve the purpose [14].

Emotional intelligence is strongly influenced by environment, dynamic, and can change anytime. Therefore, the role of environment, especially parents in childhood age plays important role in developing the child's emotional intelligence. Wrote that it needs more than one monolithic intelligence to success in life, rather a wider spectrum of intelligences that consists of linguistic intelligence, mathematical-logic, spatial, kinesthetic, musical, interpersonal, and intrapersonal intelligence is needed [15]. Defines emotional intelligence as one's ability that consists of various ability to be 
able to motivate him/herself, endure frustrations, control impulsive needs, not exaggerate happiness or difficulty, able to control reactive needs, taking care to be free of stress, not blunting the thinking ability and ability to empathize toward others, and the existence of trying while praying [15]. Further wrote that emotional intelligence is the other side of cognitive intelligence that plays a role in human activities which consists of self-awareness and controlling the impulsive needs, determination, spirit and motivation and empathy, as well as other social intelligence [15]. Emotional intelligence is rather directed toward the efforts to know, understand, and state emotions in appropriate portion and efforts to manage emotion in order for it to be controlled and able to make use emotion to solve lives problems especially related to inter human relationships.

Based on the intelligence selects interpersonal and intrapersonal intelligences as the basis for revealing emotional intelligence of individuals [16]. He proposed emotional intelligence as one's ability to recognize self-emotion, manage emotion, motivate one-self, recognize other's emotion (empathy), and ability to develop relationship (working together) with others.

Without emotional intelligence people will not be able to use their cognitive ability and their intelligence to the fullest of their potentials. There are five aspects of practical skills in managing emotions namely: (1) self-awareness, (2) motivation, (3) self control, (4) empathy, and (5) social skills. Based on these descriptions, it can be concluded that emotional intelligence is ability to demand self to learn to acknowledge and respect his/her feelings and others, and to respond toward those feelings appropriately, effectively implement the emotion energy in daily life, and is one's ability to recognize his/her own emotions, manage those emotions, selfmotivate, recognize other's emotion (empathy, and ability to develop relationship (cooperate) with others.

Spiritual intelligence (SQ) is closely related with the state of soul, mental, and one's spirituality. Some people consider SQ as the highest level of intelligence of all. This is because when someone has already had spiritual intelligence, that person is able to understand life hence, able to live wisely. The definition of spiritual intelligence itself is mental ability to develop oneself completely through various positive activities hence, able to solve problems in life by looking at the sense of the problems. Person with spiritual intelligence will be able to solve problems by looking at those problems from the positive side hence, problems can be properly solved and tends to see the meaning behind every problem. Spiritual intelligence (SQ) is evident in daily life, such as in how to act, understand life and become a wiser person in everything. Having spiritual intelligence (SQ) means having ability to act flexibly, easy to adapt with environment, able to take lesson from every event in life, hence able to become wiser in life.

\section{METHODS}

This study was conducted in one of the SMKN (vocational school) in Gorontalo, namely SMKN 1 Gorontalo. This study used qualitative approach by case study design. Based on this approach, researcher's presence in the field is necessary as the key instrument. In this research, the data that will be obtained related to development of character which based on multiple intelligences. The data consist of (1) school strategy in developing intellectual intelligence, (2) emotional intelligence, and (3) spiritual intelligence, whereas the informants are the school's principal, deputy school's principal, deputy school principal of students' affair, teachers, and students. The data collection methods were interview, observation, and documentation. The data are analyzed using individual cases analysis.

\section{RESEARCH FINDINGS AND DISCUSSION}

This study reveals that the strategy implemented by the school in development of intellectual intelligence is through: (1) quiz competition that is periodically conducted to increase critical thinking ability and creativity of the students. (2) hold creativity events for students to increase their self-confidence as well as providing outlets for students' talent. (3) Nou and Uti competition (school King and Queen competition) to increase students' self-confidence and increase their knowledge on tourism.

The school strategy in developing the students' emotional intelligence is trough activities such as: (1) self-defense training to increase their selfconfidence and discipline, (2) make the students participate in competitions in school, regions, and nationally, (3) scouts activities. Meanwhile, the school strategy in developing the spiritual intelligence of the students is trough activities, such as: (1) praying to increase students' faith and their spirituality, (2) enrich the religious events, (3) celebration or religious events. 


\subsection{School strategy in developing intellectual intelligence}

The findings showed that school's strategy in developing the intellectual intelligence of the students is implemented through some extracurricular activities, which periodically held by the school, such as:

First, quiz competition, this activity can increase students' motivation to learn, because this quiz competition will increase students' intellectual intelligence, critical thinking ability, creativity, and this type of competition motivate students to learn better. Mentioned that this type of activity is conducted through group cooperation and showed intelligence competitively [17]. This activity aims at increasing the students' creativity and critical thinking ability to create qualified generation and develop students' interest/talent to be competitive and sportive. Voiced similar idea that quiz competition requires students to answer questions and solve problems given by the teachers [18]. Learning is a process of solving the problem, because by solving the problem students will be fully developed not only their intellectuals, but also their mental and emotion [19].

Second, talent show or creativity show, this program serves to develop students' character to think creatively in accordance with their interest and talent. In which he mentioned that the current curriculum is created to prepare students to face challenges, development of knowledge, science, and technology and information, hence highly creative human resources is needed, in which they should have systematic critical thinking, logic, creative and ability to work together effectively [20]. Provision of creative environment through holistic and humanist approaches are the main characteristic in development of human resource potentials toward self-actualization [21]. Intellectual intelligence needs to be trained by doing various mental activities such as thinking, reasoning, and solving problems. Through these activities, development of character values is implemented through habituating in daily life in school [22].

Third, "Nou" and "Uti" Competition (School's King and Queen) competition. This activity is carried out to increase students' self-confidence, their personality, good character, and to have broad knowledge on tourism. Opinion where she stated that competitions held in school such as: fashion show, singing competition, poetry competition, painting competition, school's king and queen's competition, have role in shaping the competitive, creative, intelligent, skillful, responsible, dynamic, and have good character, and believe in God [23]. Therefore, self-confidence aptitude can be gained to show good social attitude with interesting arts elements.

\subsection{School strategy in developing emotional intelligence}

The findings in this study on school's strategy to develop emotional intelligence are:

First, routine self-defense training as one of the solution in building students' character emotionally to increase their self-confidence, to increase their discipline, and to create strong and healthy individual. Teenagers' emotion are often unstable, hence, their emotion needs to be developed. One of this development is through physical exercise such as sports [24]. In which he mentioned that the benefit of self-defense training is to habituate children to concentrate, focus, learn discipline, and dare to make decisions for himself/herself [25]. Thus, emotional intelligence can be trained through physical activities, such as sports exercise.

Second, participate in competitions and local and national tournaments. The tournaments are designed to develop students' character, to build their emotional intelligence, nurture sportiveness values in students, and understand students' emotion. Extracurricular activities such as, tournaments is an event provided by educational institutions as outlets for students interest, talent, hobby, personality, and creativity that can be used as tools to detect students' talents and is professionally designed, thus, becomes place to see students' great talents, develop positive characters in students, and a place for self-actualization [26]. Mentioned that the objective for implementation of National Students' Sports Olympic (O2SN) is to facilitate and motivate students who have talents in sports, hence, they can increase their skill and ability according to their subject of interest [27]. Through their participation in branch of sports locally and nationally, can nurture students' competitive values, their prestige, social values, and their sportiveness.

Third, weekend camping programs as one of the program to develop their emotional intelligence. Through this program students mental and discipline in daily lives will be developed. Stated that one form of non-formal education that is important for the development of character of Indonesians is through scouts activity [28]. Stated that scouting activities are activities which are based on scouts code called Satya and moral ethics called Darma [29]. Development of emotional intelligence in school has very important role for students to achieve best learning achievement. Mentioned that IQ only contributes by $20 \%$ for the achievement of success, whereas the rest $80 \%$ is determined by other factors of strength, one of which is emotional quotient (EQ) 
[15]. Thus, in addition to development of intellectual intelligence, development of emotional intelligence in school is equally important to be done.

\subsection{School strategy in developing spiritual intelligence}

The findings on school strategy to develop students' spiritual intelligence are:

First, students pray together as symbol of school's respect towards religious life as well as the manifestation of habituating toward students, thus, students can always practice religious practices properly in school or outside the school environment. Related to implementation of dzuhur pray in school, wrote such as, ...manifestation of obedience to Allah (God) to please Him so He might grants us heavens and protects us from hell fire, as media to know each other...etc [30].

Second, religious activity is an extracurricular activity related to spiritual intelligence that aims at increasing the faith of the students, as effort to educate students to become good adult and to teach them useful and positive things through beneficial activities. The Islamic Organization in School plays a role in the increase of religious attitude of students [31]. The objective is to motivate students to behave positively toward him/herself, toward his creator, and toward others.

Third, the zikir or remembering of God and celebration of Religious Holydays as form of school attention toward Islamic Holyday. The extracurricular activities should consider level of learners' ability and understanding [32]. That teacher has to develop students' spiritual intelligence by planning activities that can be used by the students to learn about their religions [33].

\section{CONCLUSION AND FINDINGS}

\subsection{Conclusion}

School strategy in developing intellectual intelligence of students is implemented through: (a) quiz competition, (b) talent show competition, (c) nou and uti (school's king and queen) competition, this strategy develops their competitive character, creativity, self-confidence, and their social and esthetic characters.

School strategy in developing students' emotional intelligence is through: (a) self-defense training, (b) participate in competitions or tournaments, either locally or nationally, (c) weekend camping. This strategy develops hard working characters, sportiveness, independence, and cooperation and nurture social values.

School strategy in developing students' spiritual intelligence is trough: (a) collective zuhur pray, b) religious activity, (c) zikir and celebration of Islamic holydays. This strategy develops the discipline character, good character and religious character.

\subsection{Recommendation}

Principal to be more consistent in implementing those strategies and to evaluate those strategies, teachers to participate more and to support the implementation of those strategies in school, and students to obey and implement the programs programed by the school.

\section{ACKNOWLEDGEMENTS}

Thank you for vice of principal, all teachers, and all students of SMKN 1 Gorontalo's City of for willingnes to be informant respondent for this research.

\section{REFERENCES}

[1] Postman, N. \& Weinggartner, C. The School Book: For People how Whant to Know What All the Hollering Is About. New York: Delacorte Press. Puskur, Jakarta, 1973.

[2] Sagala, S. Manajemen Berbasis Sekolah \& Mayarakat. Jakarta: PT Nimas Multima, 2004.

[3] Hoy, W. K. \& Miskel, C. G. Educational Administration Theory. Research and Practice. New York: Mc. Graw-Hill, 2011.

[4] Atmodiwirio, S. Manajemen Pendidikan Indonesia. Jakarta: Ardadizya Jaya, 2000.

[5] Komariah, A. \& Triatna, C, Visionary Leadership, Menuju Sekolah Efektif. Bandung: Bumi Aksara, 2010

[6] Samawi, M. H, Konsep dan Model Pendidikan Karakter. Bandung : PT Remaja Rosdakarya, 2011

[7] Kemendiknas. Panduan Pelaksanaan Pendidikan Karakter. Jakarta: Balitbang, 2011

[8] Burke, Mary Thomas, Jane C. Chauvin and Judith G. Miranti. 2005. Religious and Spiritual Issues in Counseling. NewYork: Brunner-Routledge

[9] Farid, M., \& Mashuri. Mengenal Inteligensi. Jakarta: Sains, 2003. 
[10] Azwar, S., Psikologi Inteligensi. Yogyakarta: Penerbit Pustaka Pelajar. 1998

[11] Tasmara, T. Spritual Centered Leadership; Kepemimpinan Berbasis Spritual. Jakarta : Gema Insani, 2006.

[12] Gardner,H. Multiple Intelelligences. Penerjemah Alexander Sidoro. Tagerang: Iteraksara, 2013

[13] Cooper, R.K. \& Sawaf, A. Executive EQ, Kecerdasan Emosional dalam Kepemimpinan dan Organisasi. Terjemahan oleh Alex Tri Kantjono Widodo. Jakarta: Gramedia Pustaka Utama, 2002

[14] Ginanjar, A., Emosional Spiritual Quotient, Rahasia Sukses Membangun Kecerdasan Emosi dan Spiritual. Jakarta: Gramedia, 2003.

[15] Goleman, D. Emosional, Kecerdasan emosional. Terjemahan oleh T. Hermaya. Jakarta: Gramedia Pustaka Utama, 2003.

[16] Goleman, D. Emotional Intelegence. New York London: Batam Book, 1996.

[17] Kurniati, A. Efektivitas Metode Expert Group dan Model Lomba Cerdas Cermat (LCC) Bagi Peningkatan Keterampilan Membaca Bahasa Arab Siswa Kelas XI MAN Kendal. Semarang: Universitas Negeri Semarang, 2015.

[18] Budiana, I Wayan. Penggunaan Teknik Cerdas Cermat Untuk Meningkatkan Kemampuan Menyampaikan Pendapat Dalam Pembelajaran Berbicara Siswa Kelas $\mathrm{VIII}_{3}$ SMP Laboratorium Undiksha Singaraja. Singaraja: Universitas Pendidikan Ganesha, 2013.

[19] Sanjaya, W. Strategi Pembelajaran Berorientasi Standar Proses Pendidikan. Jakarta: Kencana, 2008.

[20] Siswono, T.Y. Eko, dan Abdul H.R. Menilai Kreativitas Siswa. Surabaya: Universitas Negeri Surabaya, 2005.

[21] Mulyasa, E. Manajemen Pendidikan Karakter. Jakarta: Bumi Aksara, 2011.

[22] Robbins, Stephen P. \& Timothy A. Judge. Organizational Behavior. 13 Three Edition, USA: Pearson International Edition, PrenticeHall, 2009.

[23] Van Horne, S., Murniati, C., \& Saichaie, K. Student Learning Outcomes in TILE and Traditional Classrooms. Unpublished Raw Data, 2012.

[24] Hurlock, E, B. Psikologi Perkembangan. Jakarta: Erlangga, 2000.

[25] Suryadi, V. Y. Taekwondo Poomse Taeguek. Jakarta : PT . Gramedia Pustaka Utama, 2002.

[26] Anifral, H. Ekskul Olahraga Upaya Membangun Karakter Siswa. http://202.152.33.84/index.php?option=com_c ontent\&task=view\&id=16421\&Itemid $=46$.

Saturday, 2008.

[27] Sutanto, P. Pedoman Penyelenggaraan Olimpiade Olahraga Siswa Nasional (O2SN) 2016. Jakarta, 2016.

[28] Suyanto, dan Djihad H. Refleksi dan Reformasi Pendidikan di Indonesia Memasuki Milenium. Yogyakarta: Adicita Karya Nusa, 2000.

[29] Kwartir Nasional Gerakan Pramuka. Tentang Gerakan Pramuka. Jakarta, 2010.

[30] Muawanah, S. Hubungan Pembiasaan Jamaah Shalat Dhuhur Terhadap Kedisiplinan dalam Belajar Siswa. Salatiga: Sekolah Tinggi Agama Islam Negeri Salatiga, 2012.

[31] Rodliyatun, M. Peranan Pembina Kegiatan Ekstrakurikuler Rohani Islam (Rohis) dalam Meningkatkan Sikap Keberagamaan Siswa. Salatiga: Program Pascasarjana Sekolah Tinggi Agama Islam Negeri Salatiga, 2013.

[32] Departemen Agama RI. Panduan Kegiatan Ekstrakurikuler Pendidikan Agama Islam. Jakarta: Direktorat Jenderal Kelembagaan Agama Islam, 2015.

[33] Emmons, R.A . Thanks: How The New Science Of Gratitude can Make you Happier. Boston: Houghton Miflin Company, 2007. 